Copyright of Full Text rests with the original copyright owner and, except as permitted under the Copyright Act 1968, copying this copyright material is prohibited without the permission of the owner or its exclusive licensee or agent or by way of a licence its exclusive licensee or agent or by way of a licence about such licences contact Copyright Agency Limited on (02) $93947600(\mathrm{ph})$ or (02) 9394760 (fax)

\title{
Britons and Saxons In Pre-Viking Wessex: Reflections on the Law 77 of King Ine
}

\author{
Martin Grimmer
}

According to the Anglo-Saxon Chronicle, Saxons arrived in the south of Britain in the third quarter of the fifth century. Successive ship-loads of invaders progressively defeated the Britons of Kent, Sussex and southern Wessex, before moving north up the Thames Valley and beyond, establishing themselves over much of the territory of the Romano-Britons. ${ }^{2}$ Bede's Historia ecclesiastica gentis Anglorum, on which a proportion of the early material in the Chronicle is based, tells of Angle, Saxon and Jutish mercenaries invited to protect Britain from

I I would like to thank Professors Michael Bennett and Rod Thomson of the School of History and Classics at the University of Tasmania for their helpful comments on earlier drafts of this article. A modified version of it was presented at the Conference of the Australian and New Zealand Association of Medieval and Early Modern Studies, held 14 February 2000 at the University of Sydney, under the title 'Celt and Saxon: attitudes and interaction in early Wessex'. Throughout this article, the term 'Briton' will always refer to the native Celtic inhabitants of the island and never the 'Anglo-Saxons' or English. Anglo-Saxon Chronicle 449, 456/7, 477, 495, 501, and 514. All references to the Anglo Saxon Chronicle (henceforth ASC) will be cited by year from The Anglo-Saxon Chronicle, ed. Dorothy Whitelock (London: Eyre and Spottiswoode, 1965). See also Patrick SimsWilliams, 'The settlement of England in Bede and the Chronicle', Anglo-Saxon England 12 (1983), $1-41$, at p. 27, for general discussion on the Anglo-Saxon 'invasion' as portrayed in the ASC. 
foreign incursion, but who rebel against their 'cowardly British' patrons, their real intention being to subdue the island for themselves. Gildas's De excidio Britanniae, which Bede in his turn used, presents a picture of the RomanoBritons - civilianised by the Pax Romana, demilitarised by the removal of Roman troops - falling victim to the savagery of their Saxon foederati protectors. They are either massacred, forced to flee, or compelled to surrender to the Saxons as slaves.

Accounts in the primary sources such as these - of antipathy and aggression - informed traditional thinking about Anglo-British relations in Britain. Nineteenth-century scholars talked in quite vivid fire and sword imagery, of the Angles and Saxons driving back the Britons through "long and merciless struggle', and of the Britons being 'as nearly extirpated as a nation can be'.' More recent work, however, has been increasingly critical of the sources, placing them under closer scrutiny within an historiographical context. Lack of contemporaneity, ethnocentricity of outlook, and partisanship of purpose have all been complaints levelled at these early medieval accounts. In addition, it

3 Historia ecclesiastica gentis Anglorum I.15, c.449AD. All references to the Historia ecclesiastica (henceforth HE) will be cited by book and chapter number from Bede's Ecclesiastical History of the English People, ed. and trans. Bertram Colgrave and R. A. B. Mynors (Oxford: Oxford Medieval Texts, 1969). See also James Campbell, The AngloSaxons (London: Penguin, 1991), p. 26, for general comments on the Anglo-Saxon 'invasion' as portrayed by Bede.

4 Molly Miller, 'Bede's use of Gildas', English Historical Review 90 (1975), 241-261, at p. 241.

De excidio Britanniae 23.1-2; 23.5; 25.1-3, cited according to chapter and section numbers from Gildas: The Ruin of Britain and Other Documents, ed. and trans. Michael Winterbottom (London: Phillimore, 1978).

- John Richard Green, A Short History of the English People (Vol. I) (London: Macmillan, 1894), p. 17.

7 Edward Augustus Freeman, Four Oxford Lectures: Teutonic Conquest in Gaul and Britain (London: Macmillan, 1888), p. 74.

8 For example by David N. Dumville, 'Sub-Roman Britain: history and legend', History 62 (1977), 173-192; Robert W. Hanning, The Vision of History in Early Britain (New York: Columbia University Press, 1966); Nicholas Higham, Rome, Britain and the Anglo-Saxons (London: Seaby, 1992); Peter Hunter Blair, Anglo-Saxon England (Cambridge: Cambridge University Press, 1956). Arguments for greater levels of Celtic British survival in AngloSaxon England have been put ever more vigorously since the publication in 1964 of H. P. R. Finberg's Lucerna: Studies of Some Problems in the Early History of England (London: Macmillan, 1964), containing his seminal essay on the question of 'Continuity or Cataclysm?' (pp. 1-20). 
has become more apparent that there are other sources of evidence for AngloBritish interaction surviving from the seventh century and onwards which do not conform to this exclusively bellicose picture of events. Indeed, endeavouring to explore the nature of relations between the Anglo-Saxons and the Britons of early medieval Britain is to a large extent an exercise in the attempted illumination of paradox. On the one hand, there is no reason to doubt, even assuming some embellishment in the sources, that aggression and antagonism are central and continuing themes. But on the other hand, there are equally undoubted instances of less bellicose interaction. It is the aim of this article to examine one of the documentary sources that reveals this latter picture of Anglo-British relations in pre-Viking Britain, namely, the Law Code of Ine, king of Wessex c.688-726.

The Law Code of Ine was most likely promulgated between c.688-93. ${ }^{10}$ Ine's is the earliest West Saxon law code to survive, and has done so only as an appendix to the Laws of Alfred, both of which are contained at the earliest in a c.930 manuscript." The fact that Ine's laws were appended to Alfred's raises

2 ASC 688, 726 (MS. E), 728 (MS. A).

In the prologue to his Code, Ine says that he had been consulting with 'my bishop Earconwald', who died on 30 April in 693 (Patrick Wormald, The Making of English Law:King Alfred to the Twelfth Century Vol. I. Legislation and its Limits [Oxford: Blackwell, 1999], p. 103). Ine also speaks of his father Coenred as still being alive, which would also indicate a date early in his reign - although the laws may have been extended and built upon throughout his kingship. All references to Ine's laws will be cited by number from English Historical Documents c. 500-1042, ed. Dorothy Whitelock, (London: Eyre and Spottiswoode, 1955), no. 32, pp. 364-72 (henceforth EHD). An edition of the Old English text of Ine's laws, and of Alfred's referred to below, may be found in F. L. Attenborough, ed. and trans., The Laws of the Earliest English Kings (Cambridge: Cambridge University Press, 1922), pp. 36-60 and pp. 62-92 respectively.

1" See Louis M. Alexander, 'The legal status of the native Britons in late seventh-century Wessex as reflected by the Law Code of Ine', Haskins Society Journal 7 (1995), 31-8, at p. 31; and Wormald, Making of English Law, pp. 163-263. Ine's Laws and those of Alfred survive at the earliest in Corpus Christi College Cambridge MS. 173 ff. 32r-52v ('E' atso known as the 'Parker MS'), written c.930. Later manuscripts include Corpus Christi College Cambridge MS. 383 ff. 13-42 ('B') of c.1100-1125 and the Textus Roffensis ff. 9r-31v of c. 1123-4. There is also a fragment of Ine from the prologue to Ine 23 in British Library Bumey MS. 277 f. 42 dating from c.1060-70. A further manuscript, British Library Cotton MS. Otho B.xi of c. 1000-1015, was partly destroyed in the Cottonian fire of 1731, but a copy was fortunately made by Laurence Nowell in 1562, and subsequently glossed, and is contained in British Library Additional MS. 43703 (the so-called 'Nowell transcript'). Ine's and Alfred's codes are the only ones surviving for Anglo-Saxon Wessex. 
the question of whether they may have been revised or supplemented or abridged by him in the late ninth century. ${ }^{12}$ Alfred, in his own Code, states that he "left out' (forlet) those laws of Ine - and of Offa of Mercia and Aethelbert of Kent which he had not 'gathered' (gegaderode) into his own. ${ }^{13}$ This may indicate some form of abridgement. Yet it is also the case that some of Alfred's laws contradict those of Ine, ${ }^{14}$ which indicates that Alfred did not tamper with the text as it had descended to him. It should be noted that the use of the word forlet does not mean that he rejected earlier laws that he did not like, as is often claimed, but rather that he left them alone. ${ }^{16}$ This can be taken to mean, that Ine's laws were left unaltered by Alfred, except so far as they were abrogated by elements of his own code. ${ }^{17}$ So, while it remains possible that we are dealing with a redaction of Ine's Code, it does appear unlikely that the redactor was Alfred.

What is significant about Ine's Code with regard to the question of AngloBritish relations is that it is the only surviving pre-Viking Anglo-Saxon law code which actually includes explicit provision for Britons, granting them legal status. ${ }^{18}$ If we assume that laws can be defined as 'written statements of observed and enforceable social norms', ${ }^{19}$ then in codifying these social norms, Ine

12 Indeed, it should be acknowledged that the appending of Ine's Code to Alfred's was not necessarily the deliberate intention of Alfred himself. There is no statement in Alfred's introduction which indicates that this was the case; just that he consulted the laws of his predecessors. All references to Alfred's laws will be cited by number from EHD, no. 33, pp. 407-16.

13 Alfred 49.9. On this point see Wormald, Making of English Law, pp. 278-9.

14 For example, fines for theft: Ine 43, 60 shillings, compared to Alfred 9.2, 120 shillings. There are also differences in the sums levied in fighting before an ealdorman (Ine 6.2; Alfred 15 and 38), or felling another's trees (Ine 43.1; Alfred 12), or differences in the actual circumstances surrounding fighting in the king's hall (Ine 6; Alfred 7-7.1).

is Wormald, Making of English Law, pp. 103, 278; Barbara Yorke, Wessex in the Early Middle Ages (London: Leicester University Press, 1995), p. 72.

16 Wormald, Making of English Law, p. 279. Attenborough, for example, translates forlet as 'rejected' (Laws of the Earliest English Kings, p. 63).

17 I would like to thank the anonymous Parergon reviewer whose comments prompted this clarification of Alfred's code.

18 There is one other instance of a wergild structure for Britons (wealas) being included in an Anglo-Saxon text. This is the early eleventh-century re-statement of Norileoda laga by Archbishop Wulfstan II of York. See note 59.

19 Patrick Wormald, 'Laws', The Blackwell Encyclopaedia of Anglo-Saxon England, ed. Michael Lapidge, John Blair, Simon Keynes and Donald Scragg (Oxford: Blackwell, 1999), 279-80, at p. 279. Wormald also refers to Ine's laws as "Germanic' in the sense they are predicated on the mechanisms of feud'. 


\section{Britons and Saxons in Pre-Viking Wessex}

expected there to be situations in his kingdom involving Britons that could be met with by legal action. ${ }^{20}$ His Code thus unveils a West Saxon society which has Britons living within it, ${ }^{21}$ but in an inferior social position to their West Saxon counterparts, as will be shown.

There are eight laws that relate specifically to Britons: five regarding free persons, and three regarding slaves. ${ }^{22}$ The Britons are described using variations of the Old English terms wealh (plural wealas) or wyliscmon, which in origin seem to have meant 'foreigner', but which became specialised in meaning to 'Briton', and by the tenth century transformed to also denote 'slave'. Ine's Code actually contains the first Insular written occurrence of the word wealh, and we can be reasonably satisfied that 'Briton' is the correct interpretation in this context as the Code makes use of other terms for foreigner and slave: eldeodigan and deow, respectively. ${ }^{24}$ The laws pertaining to free Britons are essentially about the setting of their wergild: the sum payable to the next of kin of a slain person in order to buy off a feud. ${ }^{25}$ This was, of course, one of the two basic rights of a free person which afforded them protection in Germanic society; the other was

20 Alexander, 'Legal status of the native Britons', p. 32.

${ }^{21}$ It is worth noting that Bede also mentions Britons being subject to West Saxon authority in the final quarter of the seventh century (HE V.18).

22 Free Britons: Ine 23.3, 24.2, 32, 33, 46.1. British slaves: Ine 54.2, 74, 74.1.

23 Debby Banham, 'Anglo-Saxon attitudes: in search of the origins of Engtish racism', European Review of History 1 (1994), 143-56, at p. 150; David Pelteret, 'Slave raiding and slave trading in early England', Anglo-Saxon England 9 (1981), 99-114, at p. 107. It is from wealas that the country name 'Wales' derives.

24 For example, Ine 23 and 74 . Wealh could not yet stand alone to mean slave, but had to be qualified by deow, i.e. deowwealh. On this point see Margaret Faull, 'The semantic development of Old English wealh', Leeds Studies in English 8 (1975), 20-44, at pp. 20, 26. Faull maintained that wealh in Ine 23.3 meant both 'Briton' and 'slave', though this interpretation is questionable; see Pelteret, 'Slave raiding', p. 107, and Whitelock, EHD, p. 367. Wealh is also recorded as a personal name element in all of the four main Old English dialects (Faull, 'Semantic development of wealh', p. 31). In this regard, it should probably be allowed that the use this element in the name Cenwalh (ASC 658) appears to pre-date Ine's Code. For what it is worth, wealh may also be observed in Beowulf (line 612 ) in the person of Hrothgar's Queen Wealhdeow. In this case it is uncertain exactly what meaning should be ascribed to wealh. For an edition, see Beowulf, ed. and trans. Michael Swanton (Manchester: Manchester University Press, 1978).

${ }^{25}$ Carole Hough, 'Wergild', The Blackwell Encyclopaedia of Anglo-Saxon England, 46970 , at p. 469. 
being considered 'oathworthy', namely, able to give an oath in popular court, a right which was also extended to Ine's British subjects. ${ }^{26}$

The wergild for a Briton ranged from a maximum of 600 shillings down to a minimum of 60 shillings (see Table 1), such that: a Briton with five hides of land had a wergild of 600 shillings; a Briton who was a horse-rider (horswealh) for the king, 200 shillings; one with one hide of land, 120 shillings; a rent-payer (gafolgelda), also 120 shillings; the son of a rent-payer, 100 shillings; a Briton with half a hide, 80 shillings, and a Briton with no land, 60 shillings. ${ }^{27}$ The wergild for a Saxon, on the other hand, was not so explicitly stated. Their identity, though defined in some instances by the terms Englisc or Engliscmon, ${ }^{28}$ is principally assumed when none other is specified. Nevertheless, Saxons appear to be granted wergilds ranging from 1,200 down to 200 shillings. A member of the king's household (a geneat), had a wergild of 1,200 shillings. Elsewhere, a basis of a 200 shilling wergild is used to establish the amount of compensation due for a man killed by a raiding party with the instruction that the same formula be applied 'in the case of the nobler born'. ${ }^{30}$ This can be taken to mean that a 200 shilling man was not of the nobility and was therefore a ceorl. A further law sets out compensations for 200,600 and 1,200 shilling men, from which we might assume that a 600 man would have been of a class higher than ceorl: perhaps of the gesid class. ${ }^{31}$

Alexander, 'Legal status of the native Britons', p. 32; Patrick Wormald, 'Oaths', The Blackwell Encyclopaedia of Anglo-Saxon England, 338-9, at p. 338.

${ }^{27}$ Ine $23.3,24.2,32,33$. Ine 23.3 also states that a Briton must pay 12 shillings to avoid a flogging.

28 Ine 24, 46.1, 54.2, 74. The use of the term Englisc in the law code of a Saxon king is somewhat curious. Bryan Ward-Perkins, 'Why did the Anglo-Saxons not become more British?', English Historical Review 115 (June, 2000), 513-33, at p. 524, suggests that it might be possible the term was introduced in a later version of the text when the concept of 'Englishness' may have had more currency, perhaps in the ninth or tenth centuries.

Ine 19

${ }^{30}$ Ine 34-34.1.

"Ine 70. Gesidcund seems to have meant the same class that was referred to in the earlier Kentish laws as eorlcund. It may have been derived from an original meaning denoting a member of a king's comitatus (Whitelock, EHD, p. 362). The 200-600-1,200 differentiation can be seen more explicitly in the laws of Alfred, where it is made clear that 1,200 and 600 men are definitely not of the ceorl class (for example, Alfred 10, 18.1, 18.2, 18.3, 26, $27,28,39.2,40$ ). 
It is possible then to determine that there was a disparity between the value placed on the life of a Briton and that of a Saxon in Ine's Code. A Briton who was a horse-rider in the service of the king - a position which could reasonably be regarded as one of status ${ }^{32}$ - only attracted a wergild equivalent of a Saxon ceorl, namely, 200 shillings. While Britons could own land, they are not included in the topmost layer of society: 600 shillings is the highest wergild mentioned, in comparison with 1,200 shillings for a Saxon. Further, their status seems to be more tied to land ownership than to birthright. The wergild of Britons was essentially stratified according to how many hides of land they owned, at a rate of approximately 120 shillings per hide. A Saxon ceorl seems to have been protected at 200 shillings with no particular specification for land-ownership, though it should be allowed that the 600 and 1,200 men may have been differentiated this way.

32 A king's horse-rider is usually thought to have been a noble (Faull, 'Semantic development of wealh', p. 29), though not so elevated as a king's horsdegn (ASC 897). The horserider of Ine's Code might be compared to the 'messenger' (laadrincmannan) of Aethelbert of Kent's early seventh-century Code (Aethelbert 7, EHD, no. 29, pp. 357-9).

33 H. M. Chadwick, Studies on Anglo-Saxon Institutions (Cambridge: Cambridge University Press, 1905), pp. 93-8, argued that the difference between a 600 and a 1,200 man was that the latter owned land. In this sense, the distinction being made in Ine's Code may have been between the landless young warrior employed in the king's service (the 600 man), and the veteran who had settled down with land and family (the 1,200 man). Such a conceptualisation is echoed in the geogod (youth) versus dugud (veteran) distinction drawn in Beowulf (for example, lines 160,621). I would like the thank Dr Patrick Wonnald for drawing these references to my attention. 
TABLE 1: COMPARATTVE WERGILDS OF BRITONS AND SAXONS IN INE'S LAW CODE

\begin{tabular}{|l|l|l|}
\hline Saxons & $\begin{array}{l}\text { Wergild } \\
\text { (shillings) }\end{array}$ & Britons \\
\hline Geneat (of the king's household) & 1,200 & \\
\hline Unspecified (gesið-born?) & 600 & Owner of 5 hides \\
\hline Not of noble birth (ceorl?) & 200 & $\begin{array}{l}\text { Horswealh (in the } \\
\text { king's service) }\end{array}$ \\
\hline & 120 & $\begin{array}{l}\text { Owner of 1 hide; } \\
\text { gafolgelda }\end{array}$ \\
\hline & 100 & Son of a gafolgelda \\
\hline & 80 & Owner of no hide \\
\hline & 60 & Owner of no land \\
\hline
\end{tabular}

British slaves were also valued less than their Saxon counterparts. An oath of 12 hides was required to compel the public whipping of a British slave, however, a Saxon slave could only be whipped with a 34 hide oath. ${ }^{34}$ In general, though Britons were 'oathworthy', their word held less value than that of a Saxon; the accusation of cattle-theft could be denied by an oath to the value of 60 hides if the accuser was British, but a Saxon accuser could only be denied by an oath of 120 hides.

One can, therefore, conceptualise the society described in Ine's Code as being arranged in what Thomas Charles-Edwards refers to as a 'parallel hierarchy': it is almost as if there are two nations existing within the one polity with the Saxons in the most favourable position. ${ }^{36}$ The sense of ethnic superiority

34 Ine 54.2. Whitelock (EHD, p. 370) suggests that the original reading might have been a 24 hide oath for a Saxon slave - double the oath for a Briton - rather than a 34 hide oath. 35 This would be consistent with their comparative wergilds.

35 Ine 46-46.1.

36 Thomas Charles-Edwards, 'Anglo-Saxon kinship revisited'. In John Hines ed., AngloSaxons from the Migration Period to the Eighth Century: An Ethnographic Perspective (Suffolk: The Boydell Press, 1998), 171-210, at p. 209. 
on the part of the Saxons is not unusual in the context of Germanic law codes from the Continent. The Frankish Lex Salica, for example, distinguished GalloRomans from Franks, and recorded for them a half-wergild, and a reduced oathvalue. ${ }^{37}$ As conquered peoples, the Gallo-Romans and Britons were of inferior status and their place in the law codes reflects this. ${ }^{38}$ What is unique, rather, about Ine's Code is the relatively late date at which this differentiation occurs - the end of the seventh century - a time when it is usually argued that there was increasing diffusion and uniformity within Anglo-Saxon England, perhaps due to the influence of Christian culture.

In this context, therefore, what stands out as most remarkable about Ine's Code is that Britons were legislated for at all, a point given added emphasis when one considers their shadowy presence in the other Anglo-Saxon documentary sources. The fact of their inclusion in the Code obviously implies a large enough population of Britons in Wessex to require protection under the law. It is has been argued that in doing so, Ine was attempting to placate British interests, and that he was in a political position that required him to do so. ${ }^{40}$ The Anglo-Saxon Chronicle certainly provides evidence that during his reign, Ine was engaged on a number of his frontiers: against Kent, against Mercia, against the South Saxons, and against Geraint of Dumnonia; as well as having to deal with internal disputation within Wessex itself. ${ }^{41}$ Thus, it is possible to construct a scenario

37 The clause which most clearly distinguishes Franks and Romans is Lex Salica Title XLI, though other instances include Title XIV.1-3, Title XXXII.3-4, and Title XLII.1-4. See The Laws of the Salian Franks, ed. and trans. Katherine Fischer Drew (Philadelphia: University of Pennsylvania Press, 1991), pp. 79, 95, 104-7. On the status of Franks and Romans in the Lex Salica, see Faull, 'Semantic development of wealh', p. 21, and Wormald, Making of English Law, p. 42.

38 This point should probably not be pressed too far; it was possible for Gallo-Romans of the senatorial class to becomes bishops and counts in early Frankia.

39 Barbara Yorke, 'Settlement, Anglo-Saxon', The Blackwell Encyclopaedia of Anglo-Saxon England, 415-6. Material culture, for example, becomes more uniform - Anglian, Saxon and Jutish variations in clothing (especialty female) disappear.

41 For example, Alexander, 'Legal status of the native Britons', pp. 36-7.

4 According to the ASC: in 694 the inhabitants of Kent 'came to terms with Ine and granted him 30,000 (pounds)'. Before Ine, Caedwalla had ravaged Kent in 686 and 687 . In 715, Ine fought Ceolred of Mercia at Woden's Barrow in Wiltshire, and in 715 he fought against the South Saxons, killing Ealdberht, an aetheling he had previously expelled from Wessex. There may have been other internal disputation in Wessex, for in 721 Ine killed the aetheling Cynewulf. In addition to his military campaigns against other Anglo-Saxon kingdoms, Ine fought with Geraint, 'king of the Britons (Wealas)' of Dumnonia (i.e. Comwall and Devon), in 710 . 
whereby it was prudent for Ine to refrain from antagonising his British subjects and therefore to decrease the likelihood that he would have to deal with a rebellion at an otherwise inopportune time."

One of the difficulties, of course, with this argument is that the Britons were not afforded equal status with their Saxon counterparts, thus there is a limit to how much they might have been 'appeased' by such an arrangement. The fact that Britons had a wergild implies the king's protection, and that at least in theory they could pursue accusations against Saxons. ${ }^{43}$ But they needed twice the oathhelp of a Saxon to proceed with any accusation, and their lives were compensated at a significantly lower value. It is unlikely that the Britons would have simply accepted Ine's promulgation with naïve gratitude; there would still have existed the potential for discontent. It could equally be as likely that what Ine's Code represents was not an attempt to 'placate' British interests, but rather to set a framework for settling disputes between Saxons and Britons who had kin and indeed lords within Wessex capable of waging vendettas and disturbing the peace, making it essential for him to include them in the Code. Indeed, Ine's laws differ from the earlier Kentish codes in reflecting a more aggressive stance on enforcement and payment of fines against the social order, incorporating the king more prominently in the vocabulary of atonement."

This of course begs the question of who the Britons in Ine's Code actually were. In particular, were they descendants of Romano-Britons still living in the long-conquered eastern half of Wessex (roughly Hampshire, Wiltshire and parts of Dorset)? ${ }^{46}$ Or, given that there appears to have been a period of westward expansion in the seventh century up to and including the reign of Ine, ultimately

Yorke, Wessex, p. 72.

4. I have Professor Michael Bennett to thank for drawing this possibility to my attention.

45 Wormald, 'Laws', p. 279; idem., Making of English Law, p. 105.

4he distribution of Saxon material culture, reflected for example in grave goods, can be taken to indicate Saxon control of the eastem shires of Wessex by the end of the sixth century (Yorke, Wessex, pp. 12-13). The argument that the Britons in the code were descended from the original Romano-British inhabitants has been promoted by Leslie Alcock, Arthur's Britain: History and Archaeology AD 367-634 (Harmondsworth: Penguin Books, 1971), p. 312, and Faull, 'Semantic development of wealh', p. 23. 
encompassing Dorset, Somerset and some of Devon, ${ }^{47}$ were the Britons in the Code farmers and landowners whose land had been incorporated into a newlyenlarged Wessex?

In order to answer this question, it is first necessary to speculate on a number of matters implied by the Code. To begin with, we must assume that there existed some mechanism, some 'British' feature or features, that allowed for Britons to be recognised as such. Indeed, one of the central conclusions that can be drawn from Ine's Code regarding Anglo-British relations is that complete assimilation had not yet occurred between the two groups, such that a distinction could still be made in terms of ethnicity. There must have been some sense of British identity as distinct from Saxon identity: it would have been nonsensical to talk in terms of differentiating Britons from Saxons in the law code if it was practically impossible to do so. And indeed, it would have been important, especially for a Saxon as a person of higher status than a Briton, to be able to $b e$ differentiated given the differences in wergild. Further, the use of the term wealh - with its implication of foreign-ness - does provide some sense of British and Saxon identities being in binary opposition, ${ }^{48}$ and it is significant that the only instances in which the term Englisc is used in the Code are whenever the context involves a contrast with the Britons. ${ }^{49}$ It is, therefore, reasonable to assume that Ine's Code reflects a society that was segmented, or at least able to be segmented, on ethnic grounds.

How then would a Briton have been identified? Style of Christianity is a possibility; Britons conceivably may have continued to eschew Roman practice. However, this is unlikely to have been the case within Wessex, especially the eastern half, by the time of Ine's reign. The Synod of Hertford, which sought to extend the decisions of Whitby to the rest of the Anglo-Saxon kingdoms, had

47

The evidence of charters indicates that there was a period of westward expansion which is first documented during the reign of Centwine (676-685). See Malmesbury: S1170/ BCS71, pp. 94-7, and Glastonbury: S236/BCS61, pp. 11-5; S237/BCS62, pp. 15-7 (charters are cited by Sawyer reference number, Birch Cartularium Saxonicum edition, and page numbers from Heather Edwards' volume, The Charters of the Early West Saxon Kingdom [Oxford: British Archaeological Reports 198, 1988]).

Walter Pohl, 'Ethnic names and identities in the British Isles: a comparative perspective'. 19. In Hines, Anglo-Saxons from the Migration Period to the Eighth Century, 7-40, at p. 34.

Thomas Charles-Edwards, 'Language and society among the insular Celts 400-1000'. In Miranda J. Green, ed., The Celtic World (London: Routledge, 1995), 703-36, at p. 733. However, see note 27 regarding the use of the term Englisc. 
been held some twenty years earlier in $672 .^{50}$ About this time, Abbot Aldhelm of Malmesbury had also written to Geraint of Dumnonia, the British kingdom of the south-west, exhorting him to instruct his bishops to follow Roman practice." It is very doubtful that non-orthodox practice within Wessex would have been tolerated by the end of the seventh century.

There are a cluster of other cultural characteristics which may have operated as potential identifiers - such as dress, social custom, diet, mode of housing, style of agriculture, and so forth - but a more enduring mechanism would most likely have been language and oral culture. Language can operate as one of the most definitive markers of ethnic identity, as well as acting as a means of maintaining and reinforcing that identity. ${ }^{53}$ Indeed, Bryan Ward-Perkins argues that since the people of Ine's Wessex were Saxons, the use of the word Englisc in the Code, if it is not a later interpolation, ${ }^{54}$ suggests that it was the speaking of a particular language (i.e. 'English') that for the Saxons in Wessex was the determinant of ethnicity. Bede, of course, differentiated the peoples of Britain according to the language they spoke: English, British, Irish, and Pictish. And in the story of the Northumbrian thegn Imma who, when captured by Mercians, attempted to pass himself off as a peasant but was found out by his mode of speech, Bede also provides grounds for allowing that a person's status could be determined by how they spoke. ${ }^{37}$ While it is not being suggested here

so HE IV.5.

st On Aldhelm's letter to Geraint, see Letter IV in Michael Lapidge and Michael Herren, Aldhelm: The Prose Works (Cambridge: D.S. Brewer, 1979), pp. 155-60, and the discussion in Martin Grimmer, 'Saxon bishop and Celtic king: interactions between Aldhelm of Wessex and Geraint of Dumnonia', The Heroic Age, 4 (2001), http://member.aol.com/ heroicage 1/homepage.html.

52 John Hines, 'The becoming of the English: identity, material culture and language', AngloSaxon Studies in Archaeology and History 7 (1994), 49-59, at p. 51.

53 Della Hooke, 'The Anglo-Saxons in England in the seventh and eighth centuries: aspects of location in space'. In Hines, Anglo-Saxons from the Migration Period to the Eighth

Century, 65-99, at p. 68.

34 See note 27.

ss Ward-Perkins, 'Why did the Anglo-Saxons not become more British?', p. 524.

56 HE I.1. Bede also includes Latin as the unifying language of them all. In the Topographical Preface of the ASC MS. E, British (Brittisc) is distinguished from Welsh (Wilsc), perhaps referring to Cornish versus Welsh. When the ASC began to be compiled, these two languages would have been distinguishable. In the Topographical Preface, Latin is referred

${ }_{57}$ to as 'Book Language'.

57 HE IV.22. Charles-Edwards, 'Language and society among the insular Celts', p. 732. 
that Imma's status was necessarily revealed by the language he used, as opposed to his vocabulary or grammar or phonology, the point to be made is that it was possible to use mode of speech to differentiate amongst people in Anglo-Saxon England.

In order to accept the first proposition canvassed, that the Britons in Ine's Code were those descended from the original Romano-British inhabitants in eastern Wessex, we must assume that the language of the Britons survived and continued to be a valid marker of identity from the Invasion Period through to the end of the seventh century. We must also assume that to be a numerically significant proportion of the population, the Britons must to some extent have remained separate from the Saxons so that they could pass on their language and oral culture in such a way that their distinct identity was not extinguished by assimilation. Further, we have to assume that this policy of separation, which had been ongoing in some form for up to 200 years, at some point after Ine's reign, fell out of practice so that assimilation then began to occur, and the language of the Britons - as well as their cultural distinctiveness - disappeared to such a complete extent in eastern Britain that it had almost no influence on Old English.

It would be more reasonable to opt for the second proposition: that the Britons referred to in Ine's Code were principally those living in territory in western Wessex that was acquired in the second half of the seventh century. This westward expansion could certainly have meant an increase in the number of British subjects within Wessex, necessitating their inclusion within the law code. There would also have been less time for assimilation to occur, such that the language of the Britons could still have been spoken, and other distinctive cultural conventions still practiced. To quote Susan Reynolds, 'Apartheid is hard enough to maintain even when physical differences are obvious, political control is firm, and records of births, deaths and marriages are kept ${ }^{59}$. In other words, given the inevitable pressure to assimilate by the dominant culture, the incorporation

58 This latter point might be qualified to allow that language-borrowing from British to Old English was also impeded by the perceived lower status of the former. Thus, the limited influence of British may not have been solely due to its rapid demise within Wessex and the other Anglo-Saxon kingdoms.

s9 Susan Reynolds, 'What do we mean by 'Anglo-Saxon' and Anglo-Saxons'?', Journal of British Studies 24 (1985), 395-414, at pp. 402-3. 
of British subjects into Wessex via westward expansion in the seventh century would make it more probable that Britons could still have been readily distinguished from Saxons. ${ }^{60}$

In an article reflecting upon the Law Code of Ine, it is necessary to recognise that there is some question over the value of Germanic law codes and the extent to which they provide an accurate mirror of the society that produced them. It has been argued, for example by Patrick Wormald, that it was important in the years following the decline of the Western Empire for so-called Barbarian kings to ape Roman legal precedent and to promulgate something that looked like a written law code, irrespective of its actual judicial value. ${ }^{61}$ It was necessary for a Barbarian king's code to have had the symbolic significance of literate form so as to legitimise Barbarian rulership over conquered Roman citizens - arguably more of an issue on the Continent than in Britain, and for the fifth and sixth centuries rather than the seventh. Thus, a Germanic law code might tell us more about the image which the Barbarian kings and their advisers wished to project of themselves and their people rather than actual 'on the ground' conditions.

That being said, Wormald has also explained that such a symbolic purpose was characteristic of only certain early Germanic codes, for example, the

60 It is instructive here to note that a similar circumstance may account for the only other instance in which a wergild structure for Britons (wealas) is recorded in an Anglo-Saxon text, namely, the early eleventh-century Nordleoda laga ('Northland law') assembled by Archbishop Wulfstan II of York (1002-1023). Wulfstan reproduced virtually the same wergild structure for Britons as seen in Ine's Code, also valuing them at about half that of their Englisc counterparts. The point to be made is that immediately prior to the time of Wulfstan, the British province of Cumbria (or Cumberland) suffered invasion and annexation by English kings, for example, Edmund (ASC 945) and Aethelred II (ASC MS. E 1000). Such an eventuality no doubt resulted in the very problem that Ine had faced in seventh-century Wessex: of Britons newly living under Anglo-Saxon control. Noroleoda laga is contained at the earliest in Corpus Christi College Cambridge MS. 201 ('D') of the mid-eleventh century. For an edition, see F. Liebermann ed., Die Gesetze der Angelsachsen. Three Volumes, (Halle: M. Niemeyer, 1903-16), I, pp. 458-61, or Faull 'Semantic development of wealh', p. 25, where the relevant laws are reproduced.

6) Patrick Wormald, 'Lex scripta and verbum regis: legislation and Germanic kingship from Euric to Cnut'. In Peter Sawyer and Ian N. Wood, eds, Early Medieval Kingship (Leeds: School of History, University of Leeds, 1977), 105-38, at pp. 115, 135.

Wormald, 'Lex scripta and verbum regis', p. 136. 
irankish, Lombardic and Alamanic laws. ${ }^{63}$ Others, such as the Visigothic and Burgundian, seem rather to display real law-making in response to individual ircumstances and conditions. ${ }^{64}$ Roger Collins has also argued that these southern European codes had practical value, and similarly notes instances of Visigothic, Ostrogothic and Burgundian codes which show examples of 'case law' and of laws adapted to specific fifth- or sixth-century social realities, thus indicating that law-making was an active judicial exercise. ${ }^{65}$ In addition, Wormald states that the former group of laws did eventually evolve to become more like the latter, incorporating measures designed to deal with newly-occurring situations of real import to the peoples being legislated for. ${ }^{66}$ Thus to quote Wormald, 'kings who learned to state laws in writing as emperors were accustomed to, soon learned to make law as they had' (emphasis added). ${ }^{67}$

Ine's Code certainly appears to conform to this pattern. Even though the laws are preserved as a single text, they look more like a series of successive pronouncements, each developed to accommodate an eventuality that needed legislative attention. ${ }^{68}$ Indeed, a large number of laws give the impression that Ine was responding to particular cases as they were presented to him by petitioners. ${ }^{69}$ Strictly speaking, this of course means that not all the laws in Ine's Code are necessarily his; there could conceivably have been an original core of enactments that was added to over years or decades by his successors. ${ }^{70}$ Never-

${ }^{63}$ Patrick Wormald, 'Inter cetera bona ... genti suae: law-making and peace-keeping in the earliest English kingdoms'. In La Giustizia Nell 'alto Medioevo (vol. II), issued as Settimane di Studio del Centro Italiano di Studi Sull'alto Medioevo 42 (1995), 963-96, at p. 968.

64 Wormald, 'Inter cetera bona ... genti suae', pp. 967-8.

65 Roger Collins, 'Law and ethnicity in the westem kingdoms in the fifth and sixth centuries' in Alfred P. Smyth, ed., Medieval Europeans: Studies in Ethnic Identity and National Perspectives in Medieval Europe (Hampshire: Macmillan Press, 1998), 1-23, at pp.2, 1618.

to Wormald, 'Inter cetera bona ... genti suae', pp. 968, 980-1. See also J. M. Wallace-Hadrill,

The Barbarian West 400-1000 (Oxford: Basil Blackwell, 1985), p. 73.

67 Wormald, Making of English Law, p. 106.

${ }^{68}$ Wormald, 'Inter cetera bona ... genti suae', pp. 981-2.

69 For example, Ine 74-74.1, which sets out the legal procedure to be followed when a British slave kills a Saxon free-person; or Ine 67, a complex statement regarding procedures for the enlargement of a ploughed landholding. See Wormald, 'Laws', p. 279; and idem., Making of English Law, pp. 104, who states that Ine's Code is 'much the least organised post-Roman legal statement' and thus difficult to conceptualise as being pre-planned in its extant form.

70 Wormald, Making of English Law, p. 105. 
the-less, the conclusion of most significance here is that the Code probably does, more or less, represent conditions in Ine's time or in the time of his immediate successors.

What Ine's Code achieved was to ensure that the Saxons in Wessex, at least in a legal sense, were entrenched in the superior position. The code informs us that complete integration between Saxons and Britons had not yet occurred in Wessex. But the fact that the Code did legislate,for Britons as well as Saxons reveals one stage in the process of assimilation. II Irespective of Ine's motivation in the matter, it was possible for Britons to own land; their inclusion in the Code gives them legal standing and shows that they were part of West Saxon society. This permits us to broaden our picture of Anglo-British interaction from that gained in Gildas, Bede and the Anglo-Saxon Chronicle, to allow that relations were not exclusively antagonistic.

In addition, there does not appear to be any edict within Ine's Code which would have explicitly prohibited assimilation - beyond the truism that people of different social strata do not tend to intermingle - and at some stage after the end of the seventh century, Ine's Britons fade from the documentary record. Indeed, Ward-Perkins has recently argued that the Code may well have acted as a mechanism of social engineering which in fact encouraged assimilation. ${ }^{72}$ It was surely a liability in Ine's Wessex to be identified as a Briton, given their inferior wergilds and oath-values. It may have been Ine's deliberate policy to enact laws which were designed to compel the Britons within his kingdom to abandon their separate identity and become Saxon. ${ }^{73}$ Intermarriage between Saxons and Britons probably, therefore, took place - certain British-sounding names in the West Saxon dynasty, such as Cerdic, Ceawlin, and Caedwalla, provide some evidence here ${ }^{74}$ - and intermarriage is a customary mechanism by which language change occurs. But it is also possible that the language of the

Yorke, Wessex, p. 72.

Ward-Perkins, 'Why did the Anglo-Saxons not become more British?', pp. 523-4.

Wormald, Making of English Law, p. 106.

Personal names can be as much a matter of fashion than of ethnic descent (Reynolds, 'Anglo-Saxon and Anglo-Saxons', pp. 407-8). 
Britons was suppressed, either directly or indirectly, engulfed by the overall dominance of West Saxon political, economic and social culture. Hence, by the time Alfred promulgated his law Code in the late ninth-century, there was no apparent differentiation made between Britons and Saxons.

School of History and Classics University of Tasmania

In his will, Alfred talked of two properties he owned in Wealcynne: stating they were 'all that I have in Wealcynne'. Simon Keynes and Michael Lapidge translate this term explicitly as Cornwall, and not as meaning amongst Britons within Wessex proper (Alfred the Great: Asser's 'Life of King Alfred' and other Contemporary Sources [Harmondsworth: Penguin, 1983]), 173-8, at p. 175). 